\title{
Current practice of induction of labour and maternal outcome in $\geq 37$ week of gestation: an observational study
}

\section{Jil Manishkumar Sheth, Anjani Shrivastava, Kedar Trivedi*}

Department of Obstetrics and Gynecology, Government Medical College, Surat, Gujarat, India

Received: 16 June 2021

Accepted: 13 July 2021

Revised: 14 July 2021

\author{
*Correspondence: \\ Dr. Kedar Trivedi, \\ E-mail: Kedatri@gmail.com
}

Copyright: ( ) the author(s), publisher and licensee Medip Academy. This is an open-access article distributed under the terms of the Creative Commons Attribution Non-Commercial License, which permits unrestricted non-commercial use, distribution, and reproduction in any medium, provided the original work is properly cited.

\section{ABSTRACT}

Background: As we know induction is done when benefit to mother and fetus overweigh benefits of continuing the pregnancy. According to NICE guidelines, induction of labor leads to $15 \%$ of instrumental deliveries and $22 \%$ of total LSCS. In new civil hospital, Surat (according to 2017) failure of induction of labor was 2nd most common indication of LSCS. The objective of this study were to analyse labor induction with respect to indication for induction of labor and its maternal outcome so that we optimize our protocol of labor and reduce our LSCS rates for the same, can reduce feto-maternal morbidities also.

Methods: This was prospective observational descriptive study carried out over duration of 6 month. 200 consecutive cases of consenting women requiring induction of labour and fulfilling inclusion criteria were selected. Induction was done with prostaglandin analogous. Data were collected includes age, parity, gestational age, bishop score, indication of induction, and maternal outcome. And data was analyzed by using EMI software.

Results: Timely induction of labor can reduce maternal morbidity and ensure the delivery of a healthy baby. Among 200 consenting women $58.5 \%$ were multigravida and $41.5 \%$ were primigravida. Most common indication of induction among study participants is prolong rupture of membrane which is $35.5 \%$. Among them $71.4 \%$ had vaginal delivery having poor bishop score. Most common indication for LSCS were fetal distress $(34.8 \%)$.

Conclusions: We concluded that elective induction of labor was associated with lower rates of LSCS and improved maternal and neonatal outcome.

Keywords: Induction, Bishop score, Maternal outcome

\section{INTRODUCTION}

Induction implies stimulation of contractions before the spontaneous onset of labour, with or without rupture membranes. ${ }^{1}$ Induction is done when benefit to mother and the foetus over weigh benefits of continuing the pregnancy. Maternal risk of prolong pregnancy includes emergency caesarean section, post-partum haemorrhage and puerperal infection. There could be some specific conditions like: (a) term pre-labor rupture of membranes; (b) hypertensive disorders in pregnancy; (c) post-dated pregnancy; (d) pre-term pre-labor rupture of membranes; and (e) uncontrolled diabetes of pregnancy. Inducing agent prostaglandin E2 (dinoprost gel) that increases the collagenase and hyaluronidase levels in cervix and increase the submucosal water content that lead to softening of cervix. It can cause uterine hyper-stimulation. Another inducing agent prostaglandin E1 (misoprostol) is less expensive, more stable and easier to store than PGE1. In this study we have seen the various indication of labour, its percentage and outcome of induction of labor.

\section{Aim and objective}

The aim of the study was to study the indication for induction of labour $\geq 37$ weeks of pregnancy. The objective 
of this study was to determine maternal outcome like mode of delivery and delivery complications of induction of labour.

\section{METHODS}

This observational, prospective study was carried out in department of obstetrics and gynaecology, government medical college surat enrolling 200 consecutive subjects fulfilling inclusion criteria with $\geq 37$ weeks of pregnancy admitted to labor room over a period around 1 year from April 2018-April 2019, after obtaining approval from ethical committee.

\section{Inclusion criteria}

The study included all singleton pregnancy with cephalic presentation at NCHS after 37 weeks of gestation.

\section{Exclusion criteria}

Patients with gestational age $<37$ weeks, fetal mal presentation, previous caesarean delivery or h/o any surgery over uterus, IUFD were excluded.

\section{Data collection tools and statistical analysis}

Induction was done either with dinoprost gel $(0.5 \mathrm{mg})$ inserted intracervically or tablet misoprostol $(25 \mathrm{mcg}) \mathrm{kept}$ intravaginally at post fornix. Induced subjects were monitored in labor room with continues fetal heart monitoring. after delivery feto-maternal outcome in view of mode of delivery, indications for LSCS, and neonatal condition were recorded. Collected data were complied, managed, analysed and presented using student version of statistical package for social sciences software and MS excel.

The possible association between variables mentioned below was found using a Chi square test ( $\mathrm{p}$ value $<0.05$ was considered statistically significant).

\section{RESULTS}

This study is prospective observational study on fetomaternal outcome of induction of labour $\geq 37$ weeks of pregnancy.

In this study, 200 subjects fulfilling the inclusion criteria were taken. patients were induced either with dinoprost gel $0.5 \mathrm{mg}$ intracervically or $25 \mathrm{mcg}$ tab misoprostol intravaginally. The demographic characteristics were comparable with respect to maternal age, parity and gestational age, indication for induction of labour and indication for LSCS. The outcome was compared were mode of delivery, the induction to delivery interval, maternal complications and fetal outcome. In our study primigravida subjects were $41.5 \%$ and multigravida patients were $58.5 \%$. Majority of subjects were multigravida.
185 subjects had Bishop score was $\leq 6$. And most common indication for induction was PROM which was $35.5 \%$. followed by $30.5 \%$ due to post-datism.

Out of 200 subjects 145 subjects had normal vaginal delivery and 55 subjects need operative intervention. Most common indication for LSCS was fetal distress: 16 (34\%). And non-progress of labour was $2^{\text {nd }}$ most common indication for LSCS: 8 (17.4\%).

98 subjects deliver within 12 hours of induction. Maternal complication was observed in $12 \%$ of cases. Out of that rupture uterus was observed in $0.5 \%$ cases, infection in $5 \%$ cases and post-partum haemorrhage in $6.5 \% .77 .8 \%, 4.3 \%$, and $17.9 \%$ cases of multigravida were delivered by vaginal, instrumental, and LSCS respectively and $65.1 \%$, $4.8 \%$ and $30.1 \%$ cases of primigravida were delivered by vaginal, instrumental and LSCS respectively. The difference of mode of delivery according to parity was statistically significant. This observation was comparable with Thrishna study given below in discussion.

$88.9 \%$ and $11.1 \%$ cases of multigravida have Bishop's score was $<6$ and $\geq 6$ and $97.6 \%$ and $2.4 \%$ cases of primigravida have Bishop's score was $<6$ and $\geq 6$ respectively. Which was statistically significant. Subject's with Bishop score $<6,1.4 \%$ had vaginal delivery, $4.3 \%$ had instrumental delivery and $24.3 \%$ had LSCS. With Bishop score of $\geq 6,86.6 \%$ had vaginal delivery, $6.7 \%$ had instrumental delivery and $6.7 \%$ had LSCS. In primigravida mode of delivery and Bishop score was statistically not significant. In multigravida this both parameters were statistically significant.

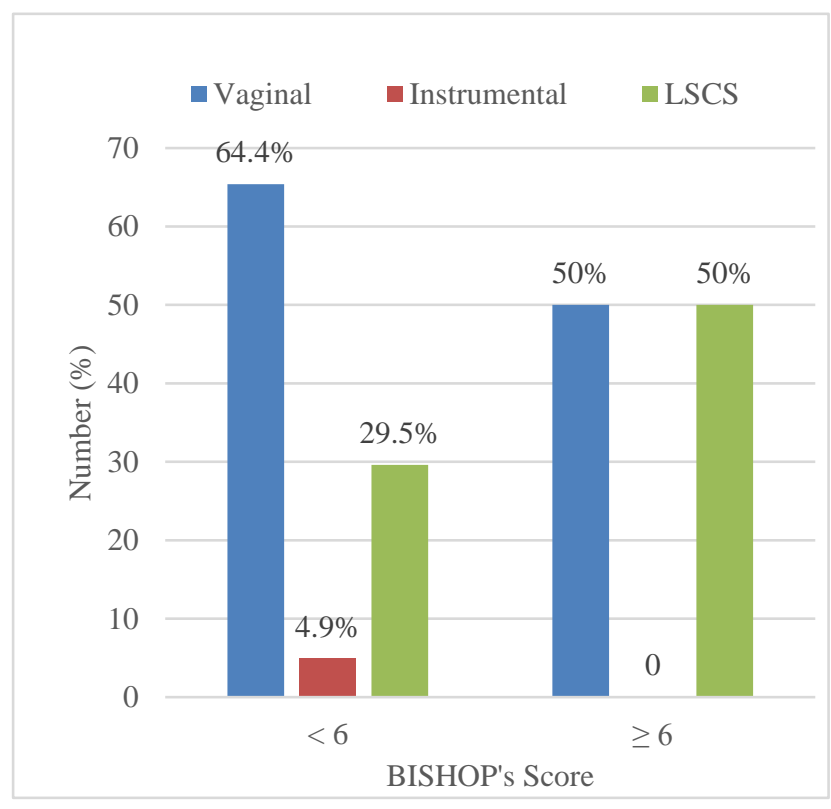

Figure 1: Association between primigravida cases and mode of delivery according to Bishop's score $(\mathrm{N}=83)$.

Primigravida cases have Bishop's score was $<665.4 \%$ had normal vaginal delivery, $4.93 \%$ had instrumental and 
$29.6 \%$ had LSCS. Subjects with Bishop score $\geq 6,50 \%$ had vaginal delivery and $50 \%$ had LSCS. The difference of Bishop's score of primigravida cases according to MOD was statistically not significant $(p>0.05)$. In primigravida other factors are also associated with mode of delivery like abnormal position of head, prolong latent phase compared to multigravida. According to Lamichhane et al, Subedi et al, Banerjee at al a stusy on outcome of induction of labora prospective study; even though most of the patients had poor Bishop score, $67.7 \%$ of patient had vaginal delivery. ${ }^{2}$ Induction with prostaglandins analogous is effective in cervical ripening and vaginal delivery can be anticipated even in patient with poor Bishop.

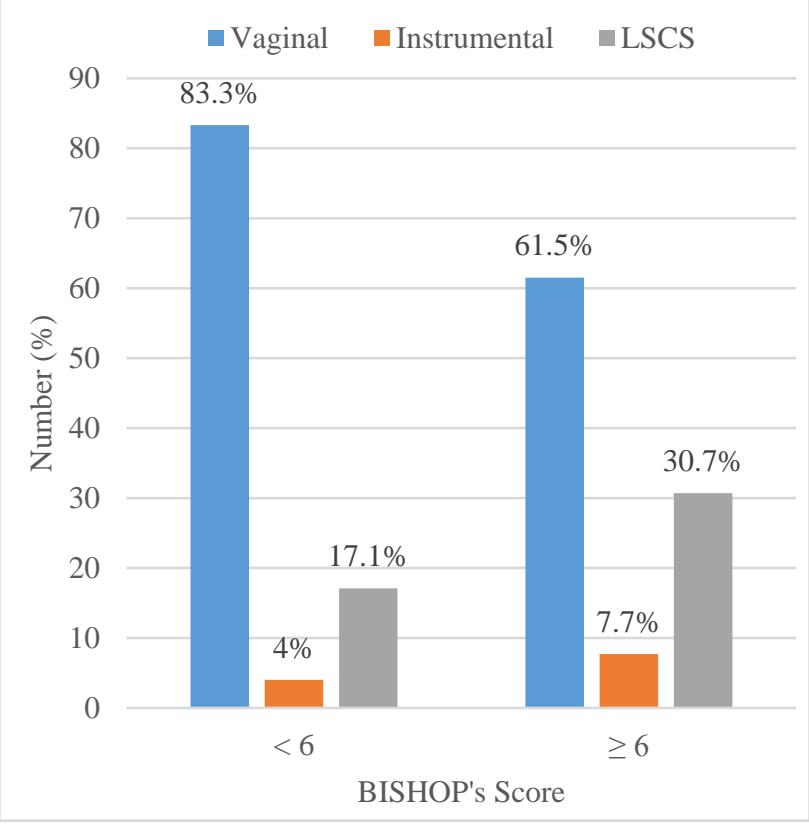

Figure 2: Association between multigravida cases and MOD according to Bishop's score $(\mathrm{N}=117)$.

Multigravida cases have Bishop's score was $<6$ had $83.3 \%$ had vaginal delivery, $4 \%$ had instrumental delivery and $17.1 \%$ had LSCS. Subjects with Bishop score of $\geq 6$ had $61.6 \%$ vaginal delivery, $7.7 \%$ had instrumental and $30.7 \%$ had LSCS. The difference of Bishop's score of primigravida cases according to MOD was statistically significant $(\mathrm{p}<0.05)$.

Table 1: Indication of induction among study participants $(\mathrm{N}=\mathbf{2 0 0})$.

\begin{tabular}{|ll|}
\hline Indication of induction & Number (\%) \\
\hline Post-datism & $61(30.5)$ \\
\hline PROM & $71(35.5)$ \\
\hline Oligohydramnios & $31(15.5)$ \\
\hline PIH & $16(8.0)$ \\
\hline PLP & $15(7.5)$ \\
\hline IUGR & $1(0.5)$ \\
\hline GDM & $1(0.5)$ \\
\hline Post-datism + oligohydramnios & $4(2.0)$ \\
\hline
\end{tabular}

In present study PROM as the indication of induction in $35.5 \%$ participants and post-datism, oligohydramnios, PIH, PLP, IUGR, GDM, and post datism+oligohydramnios in $30.5 \%, 15.5 \%, 8.0 \%, 7.5 \%$, $0.5 \%, 0.5 \%$ and $2.0 \%$ respectively. According to Acharya, Devkota, and Bhattarai study done for outcome of misoprostol and oxytocin in induction of labour: it was found that post-dated pregnancy was the major indication for IOL, that is, $70.2 \%$ followed by gestational hypertension $7.3 \%$.

According to Lamichhane, Subedi, Banerjee, Bhattarai, study was done on outcome of induction of labour: prospective study; post-dated pregnancy was most common indication $(44.5 \%)$ for induction of labour $\mathrm{f} / \mathrm{b}$ PROM (19.6\%), PPROM (7\%), PIH (12\%), oligohydramnios $(11.5 \%)$ and others like gestational diabetes mellitus, IUFD.

Table 2: Indication of LSCS (N=46).

\begin{tabular}{|ll|}
\hline Indication of LSCS & Number (\%) \\
\hline Fetal distress & $16(34.8)$ \\
\hline Non-progress of labor & $11(23.9)$ \\
\hline Failure of induction & $8(17.4)$ \\
\hline Meconium stain liquor & $9(19.6)$ \\
\hline Suspected chorioamniotis & $2(4.3)$ \\
\hline
\end{tabular}

In present study fetal distress was the indication of LSCS in $34.8 \%$ participants and nonprogress of labour, failure of induction, MSL and suspected chorioamniotis in $23.9 \%$, $17.4 \%, 19.6 \%$ and $4.3 \%$ respectively.

\section{Suspected chorioamniotis}

(a) Primigravida 37 weeks pregnancy presented with prelabour rupture of membranes for 4 hours with Bishop score: 2 . 2 times induction was done with cerviprime gel. After that she had fever, tachycardia, fetal tachycardia and hypotension. She was taken for EMLSCS; (b) Multigravida 39 weeks of pregnancy presented with prelabour rupture of membrane for 12 hours with Bishop score; (c) After 1 time of induction she had uterine tenderness, fetal tachycardia, fever, maternal tachycardia and leukocytosis. EMLSCS was done.

According to Lamichhane, Subedi, Banerjee, Bhattarai, study was done on outcome of induction of labour: prospective study; most common indication for LSCS in our study was failed induction, which was around $44 \%$. The second common indication was fetal distress, which was $29 \%$. Similar study done by Park et al reported that the rate of cesarean section for failed induction was $33 \% .{ }^{17}$

According to study conducted at Dhaka Medical College: analyze that $55 \%$ cesarean was due to failed induction and 45\% were due to fetal distress. ${ }^{17,18}$ According to Acharya, Devkota, and Bhattarai study done for outcome of misoprostol and oxytocin in induction of labour: $61 \%$ LSCS were due to fetal distress (most common), failure of 
induction was second most common case of lscs which was $23.5 \%, 5.9 \%$ were non-progress of labour, $1.5 \%$ were due to suspected chorioamniotis and others were $7.4 \%$.

Table 3: Maternal complications ( $\mathrm{N}=\mathbf{2 4})$.

\begin{tabular}{|ll|}
\hline Complications & Number (\%) \\
\hline Rupture uterus & $1(0.01)^{*}$ \\
\hline Infections (puerperal pyrexia) & $10(5)$ \\
\hline Post-partum haemorrhage & $13(6.5)$ \\
\hline
\end{tabular}

Note: *progress of labour. Emergency cesarean section was performed and ruptured uterus was noted intraoperatively. She had previous 3 normal vaginal deliveries. She delivered a $3.2 \mathrm{~kg}$ of female baby.
Study shows that maternal complication was observed in $12.0 \%(24 / 200)$ cases. Out of that, rupture uterus was observed in $0.01 \%$ cases, infection in $5 \%$ cases and postpartum hemorrhage in $6.5 \%$ cases.

\section{DISCUSSION}

Below table compares our present study with other studies. All studies are prospective observational studies. And have included singleton with vertex presentation. All these studies included subjects have gestational age $\geq 37$ weeks. The primary outcome of these studies had spontaneous vaginal delivery and most common indications for LSCS fetal distress.

Table 4: Comparison of presence study with others studies.

\begin{tabular}{|c|c|c|c|c|}
\hline Study & Present study & Acharya et al ${ }^{15,16}$ & Lamicchane et al $^{2}$ & Sultana et al ${ }^{17,18}$ \\
\hline Study design & $\begin{array}{l}\text { Prospective } \\
\text { Observational }\end{array}$ & $\begin{array}{l}\text { Prospective } \\
\text { observational }\end{array}$ & $\begin{array}{l}\text { Prospective } \\
\text { observational }\end{array}$ & $\begin{array}{l}\text { Prospective } \\
\text { observational }\end{array}$ \\
\hline Inclusion criteria & $\begin{array}{l}\text { Single tone live, } \\
\text { vertex presentation } \\
\text { with } \geq 37 \text { weeks of } \\
\text { gestation. }\end{array}$ & $\begin{array}{l}\text { Single tone live, } \\
\text { vertex presentation } \\
\text { with } \geq 37 \text { weeks of } \\
\text { gestation. }\end{array}$ & $\begin{array}{l}\text { Single tone live, } \\
\text { vertex presentation } \\
\text { with } \geq 37 \text { weeks of } \\
\text { gestation. }\end{array}$ & $\begin{array}{l}\text { Single tone live, } \\
\text { vertex presentation } \\
\text { with } \geq 40 \text { weeks of } \\
\text { gestation. }\end{array}$ \\
\hline Sample size & 200 & 205 & 391 & 50 \\
\hline $\begin{array}{l}\text { Indication for } \\
\text { induction }\end{array}$ & $\begin{array}{l}\text { Most common } 35.5 \% \\
\text { PROM, } 2 \text { most } \\
\text { common } 30 \% \text { post- } \\
\text { datisms, } 14.5 \% \\
\text { oligohydroamnios. }\end{array}$ & $\begin{array}{l}\text { Most common } \\
70.2 \% \text { post-datism } \\
\text { and } 2^{\text {nd }} \text { most } \\
\text { common gestational } \\
\text { hypertension } 7.3 \%\end{array}$ & $\begin{array}{l}\text { Most common post- } \\
\text { datism } 44.5 \% \text {, PROM } \\
19.6 \% \text {, } \\
\text { oligohyroamnios } \\
11.5 \%\end{array}$ & $\begin{array}{l}\text { Induction done for } \\
\text { post-datism }\end{array}$ \\
\hline \multicolumn{5}{|c|}{ Mode of delivery (\%) } \\
\hline Vaginal & 72.5 & 64.9 & 62.91 & 48 \\
\hline Instrumental & 4.5 & 1.9 & 4.86 & 12 \\
\hline LSCS & 23 & 33.2 & 32.23 & 40 \\
\hline \multicolumn{5}{|c|}{ Indication for LSCS } \\
\hline Fetal distress & 34.8 & 61.8 & 29 & 55 \\
\hline Failed induction & 13 & 23.5 & 44 & 45 \\
\hline $\begin{array}{l}\text { Non-progress of } \\
\text { labour }\end{array}$ & 21.7 & 5.9 & & \\
\hline $\begin{array}{l}\text { Maternal } \\
\text { complications }\end{array}$ & $\begin{array}{l}6.5 \% \text { had post-partum } \\
\text { hemorrhage and } 5 \% \\
\text { had fever. }\end{array}$ & $\begin{array}{l}36.7 \% \text { had nausea } \\
\text { and vomiting and } \\
24.1 \% \text { had fever. }\end{array}$ & & $\begin{array}{l}16 \% \text { had abnormal } \\
\text { uterine contraction } \\
\text { and } 8 \% \text { had post- } \\
\text { partum haemorrhage }\end{array}$ \\
\hline
\end{tabular}

\section{Strengths}

One of the strength of our study was the inclusion of study data on feto-maternal outcome in view of mode of delivery, induction to delivery interval and maternal complication in induction of labour in women with postdated pregnancy, PROM, oligohydramnios, PIH, PLP, IUGR, and GDM. The overall risk of bias of the included studies was low as consecutive 200 cases were taken.

\section{Limitations}

In our study we only induced patient with medical indications. We had not incuded elective inductions. So, this study not give any result about feto-maternal outcome in elective induction of labour. Induction must be weighed against the potential for decrease patient's satisfaction, increased use of inducing agents for labour process and impact on breast-feeding and cost and resource use. This study did not included the women with previous caesarean section, women with gestational age $\leq 37$ weeks of pregnancy, women having twins pregnancy, and women having IUFD.

\section{CONCLUSION}

From our study we conclude that when induction is undertaken for appropriate reason and with a safe and efficient approach, this can greatly benefit the health of both mother. Although Bishop score is poor, Successful 
vaginal delivery occur in majority of cases, where induction of labour is done in unfavourable conditions of pregnancy such as pre-eclampsia, oligohydroamnios, postdatism. Study conclude that induction did not increase the rate of caesarean section. Timely induction of labour can reduce maternal and perinatal morbidity. Further, prospective studies are needed to better assess the full impact of induction on maternal morbidity, maternal wellbeing and cost.

\section{ACKNOWLEDGMENTS}

Authors would like to acknowledge obstetrics and gynaecology department staff, all participants for their consent during study.

\section{Funding: No funding sources}

Conflict of interest: None declared

Ethical approval: The study was approved by the Institutional Ethics Committee

\section{REFERENCES}

1. Cunningham FG, Leveno KJ, Bloom SL, Dashe JS, Barbara L. Williams obstetrics. 24th ed. New York, NY: McGraw Hill; 2014.

2. Leduc D, Biringer A, Lee L, Dy J, Clinical Practice Obstetrics Committee; Special Contributors. Induction of labour. J Obstet Gynaecol Can. 2013;35(9):840-57.

3. Macer JA, Macer CL, Chan LS. Elective induction versus spontaneous labor: a retrospective study of complications and outcome. Am J Obstet Gynecol. 1992;166(6):1690-6.

4. McKinney E, Ashweil J, Murray S, James S, Gorrie T, Drokse S. Maternal Child Nursing. Philadelphia: WB Saunders: 2000.

5. Cunningham FG, Leveno KJ, Bloom SL, Dashe JS, Barbara L. Williams obstetrics. 25th ed. New York, NY: McGraw Hill; 2018.

6. Taipale P, Hiilesmaa V. Predicting delivery date by ultrasound and last menstrual period in early gestation. Obstet Gynecol. 2001;97(2):189-94.

7. Barr WB, Pecci CC. Last menstrual period versus ultrasound for pregnancy dating. Int $\mathrm{J}$ Gynaecol Obstet. 2004;87(1):38-9.
8. Hamm RF, Downes KL, Srinivas SK, Levine LD. Using the Probability of Cesarean from a Validated Cesarean Prediction Calculator to Predict Labor Length and Morbidity. Am J Perinatol. 2019;36(6):561-6.

9. Grobman W. A randomized trial of elective induction of labor at 39 weeks compared with expectant management of low-risk nulliparous women. Am J Obstet Gynecol. 2018;218(1):601.

10. Middleton P, Shepherd E, Flenady V, McBain RD, Crowther CA. Planned early versus expectant management (waiting) for prelabor rupture of membranes at term (37 weeks or more). Cochrane Database of Syst Rev.2017;4(1):5302.

11. The Royal Australian and New Zealand College of Obstetricians and Gynecologists, Excellence in Women's Health. Term Prelabour Rupture of Membranes (Term PROM). 2017.

12. Koopmans CM, Bijlenga D, Groen H, Vijgen SM, Aarnoudse JG, Bekedam DJ, et al. Induction of labour versus expectant monitoring for gestational hypertension or mild pre-eclampsia after 36 weeks' gestation (HYPITAT): a multicentre, open-label randomised controlled trial. Lancet. 2009;374(9694):979-88.

13. Wang Y, Hao M, Sampson S, Xia J. Elective delivery versus expectant management for pre-eclampsia: a meta-analysis of RCTs. Arch Gynecol Obstet. 2017;295(3):607-22.

14. Spiegel E, Weiner Z, Shlomo I, Shalev E. For how long should oxytocin be continued during induction of labour?. BJOG. 2004;111(4):331-4.

15. Ngoc NT, Merialdi M, Aleem H, Carroli G, Purwar $\mathrm{M}$, Zavaleta N, et al. Causes of stillbirths and early neonatal deaths: data from 7993 pregnancies in six developing countries. Bull World Health Organ. 2006;84(9):699-705.

16. Fernand A. Prolong Pregnancy: Practical guide to high risk pregnancy and delivery. 4th ed. India: Elsevier; 1997: 150-152.

17. Decency A, Nathan L, Laufer N, Roman AS. Current Obstetrics and Gynecology- Diagnosis and treatment. 10th ed. New York, NY: McGraw Hill; 2007; 281.

Cite this article as: Sheth JM, Shrivastava A, Trivedi K. Current practice of induction of labour and maternal outcome in $\geq 37$ week of gestation: an observational study. Int J Reprod Contracept Obstet Gynecol 2021;10:3132-6. 